\title{
FUNGOS E LEVEDURAS NO ESTUÁRIO DA LAGOA DOS PATOS E PRAIA DO CASSINO, RS, BRASIL
}

\author{
ERICA S. SILVEIRA ${ }^{1}$; RUBENS CÁURIO LOBATO ${ }^{2}$; PAULO CESAR ABREU ${ }^{3}$
}

${ }^{1}$ Post-Graduation Course on Biological Oceanography, Federal University of Rio Grande - FURG, Rio Grande, RS, Brazil. Mailing adress: Rua Anchieta, no1416, apto 302, Pelotas, RS, Brasil. Cep.: 96015.420.; tel.: (5553) 99831656, (5553)32336535).; Email: erisil_67@yahoo.com.br ${ }^{2}$ Post-Graduation Course on Biological Oceanography, Federal University of Rio Grande - FURG, Rio Grande, RS, Brazil. ${ }^{3}$ Institute of Oceanography, Federal University of Rio Grande - FURG, Rio Grande, RS, Brazil.

\section{ABSTRACT
FUNGI AND YEASTS IN THE PATOS LAGOON ESTUARY AND CASSINO BEACH, RS, BRAZIL}

This study evaluated the spatial and temporal variability of the fungi and yeasts in the waters of the estuarine region of the Patos Lagoon and the adjacent oceanic Cassino Beach. Water samples was sampled monthly (March 2007 to June 2008) from three sites the richness of fungi was assessed by cultivating the samples in Sabouraud agar plates with Chloramphenicol. Environmental variables like water temperature, salinity, $\mathrm{pH}$ and dissolved inorganic nutrients (phosphate ammonium, nitrite and nitrate) were also analyzed. The most common fungal genera found were Aspergillus, Penicillium, and clusters of nonsporulating fungi and yeasts. Fungi distribution was mainly affected negatively by salinity and positively by ammonium and phosphate.

KEYWORDS: spatial variability, temporal variability, salinity, nutrients

\section{RESUMO}

Este estudo avaliou a variabilidade espacial e temporal dos fungos e leveduras nas águas da região estuarina da Lagoa dos Patos e praia do Cassino. Amostras de água foram coletadas mensalmente pelo período de um ano em três pontos distribuídos ao longo do estuário da Lagoa dos Patos e região costeira adjacente. A riqueza de fungos foi avaliada através de cultivos das amostras em placas com ágar Sabouraud com Cloranfenicol. Variáveis ambientais como temperatura da água, salinidade, $\mathrm{pH}$ e nutrientes inorgânicos dissolvidos (fosfato, amônia, nitrito e nitrato), também foram analisados. Os gêneros de fungos mais encontrados foram Aspergillus, Penicillium, e agrupamentos de fungos não-esporulados e leveduras. A distribuição de fungos foi afetada negativamente pela salinidade e positivamente pelas concentrações de amônia e fosfato.

PALAVRAS-CHAVE: variabilidade espacial, variabilidade temporal, salinidade, nutrientes

\section{INTRODUCTION}

Fungi are micro- or macroscopic eukaryotic organisms with cell walls composed of chitin found in all environments (terrestrial, aquatic and aerial ones). They reproduce asexually and/or sexually and are classified as heterotrophic, with saprophagic behavior (Alexoupoulos et al. 1996). Fungi are ubiquitous in the water, but their distribution is influenced by geographical location and substrates (Jones \& Alias 1997, Gareth et al. 2006).

Truly aquatic fungi and those that can be found in aquatic environments differ greatly in that the aquatic fungi depend on water for reproduction and have special morphological adaptations that allow the life in the water (Sparrow 1968, Dick 1970). Terrestrial fungi might use water as a vehicle for transporting their dispersal units, or can be carried to aquatic environments by wind, leaching, or attached to allochthonous organic substrates (Sparrow 1968, Dick 1970).

There is scant information about fungi found in aquatic environment in South America coastal marine environments. In Brazil, few studies reported the occurrence of fungi (Gomes et al. 2008, Silva et al. 2003) and yeasts (Faraco \& Faraco 1960, Queiroz 1972, Loureiro et al. 2005) in these environments.
Fungi have a fundamental role in maintaining ecosystems balance, considering their activity in the decomposition of organic matter and nutrient recycling. These microorganisms are also important in improving the nutritional quality of organic substrate consumed by detritivorous organisms. Some fungi can remove or degrade inorganic and recalcitrant pollutants, in this case functioning as water purifiers (Schoenlein-Crusius et al. 2004). Studies aimed at the identification of microorganism species are important in providing a better understanding of biodiversity and aquatic ecology, but also as alternative to obtain bioproducts and biotechnological processes (Vasconcelos et al. 2003).

The estuarine region of the Patos Lagoon, RS has high rates of primary productivity and a considerable biological diversity (Seeliger \& Castelo 1997). It is a reproduction and nursery area of many marine fish and crustacean species, which find protection and food in this environment. Detritivorous food chain prevails in this ecosystem, where the biomass of higher plants is decomposed by bacteria and fungi, turning the matter and energy produced by plants available to aquatic consumers (Seeliger \& Castelo 1997).

Some studies have been conducted on the ecology of bacteria and protozoans in the Patos Lagoon estuary and revealed that the dynamics of the bacterial 
community is determined by biological factors such as phytoplankton primary production and the bacterivory carried out by protozoans (Abreu et al. 1992). Brepohl et al. (1996) followed the biomass variation bacteria, flagellates and ciliates during the degradation process of Scirpus maritimus (macrophyte) leaves, measuring the influence of released dissolved organic matter on the community of free and attached bacteria. A large amount of fungal spores was found during the decomposition of three macrophyte species (Spartina alterniflora, Spartina densiflora and Scirpus maritimus) in the same region (Hickenbick et al. 2004). Despite the great ecological importance and biotechnological potential of fungi and yeasts found in aquatic environment little is known about their diversity and abundance in the Brazilian coastal region, especially in the Patos Lagoon estuary. Therefore, this study aimed to evaluate the spatialtemporal variability of the fungi and yeasts community in the Patos Lagoon estuary and adjacent coastal area (Cassino Beach) and possible environmental variables that influence their distribution.

\section{MATERIAL AND METHODS}

Sites, Sampling and abiotic variables:

Two sampling sites in the estuary of Patos Lagoon (Museum - Oceanographic Museum of FURG, and of Channel - at the lagoon main outflow channel) and one at Cassino Beach (Beach) (Figure 1) were visited monthly, between March 2007 and June 2008. No fungi isolation was conducted in the months of July and August 2007 and February and March 2008. At each site three samples of $500 \mathrm{~mL}$ water were collected, using sterilized wide mouth glass flasks $(5 \mathrm{~cm}$ in diameter) (Wheaton model). Each flask was quickly submerged with the mouth down, $30 \mathrm{~cm}$ below the surface.

Water temperature (thermometer Incoterm $1^{\circ}-100^{\circ} \mathrm{C}$ ), salinity (Hand Refractometer ATAGO S0 MILL/-E), $\mathrm{pH}$ (pH meter DIGIMED DMPH-3) and water transparency (Secchi Disk) were recorded at each sampling site. Subsequently, in the laboratory, the concentrations of the dissolved inorganic nutrients phosphate, nitrate+nitrite (Strickland \& Parson 1972) and ammonium (Unesco 1983) were analyzed.

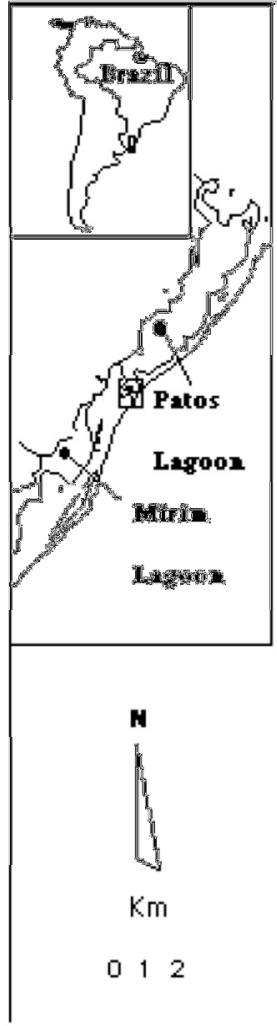

Figure 1. Localization of the sampling sites: 1- Museu 2 - Barra 3 - Praia

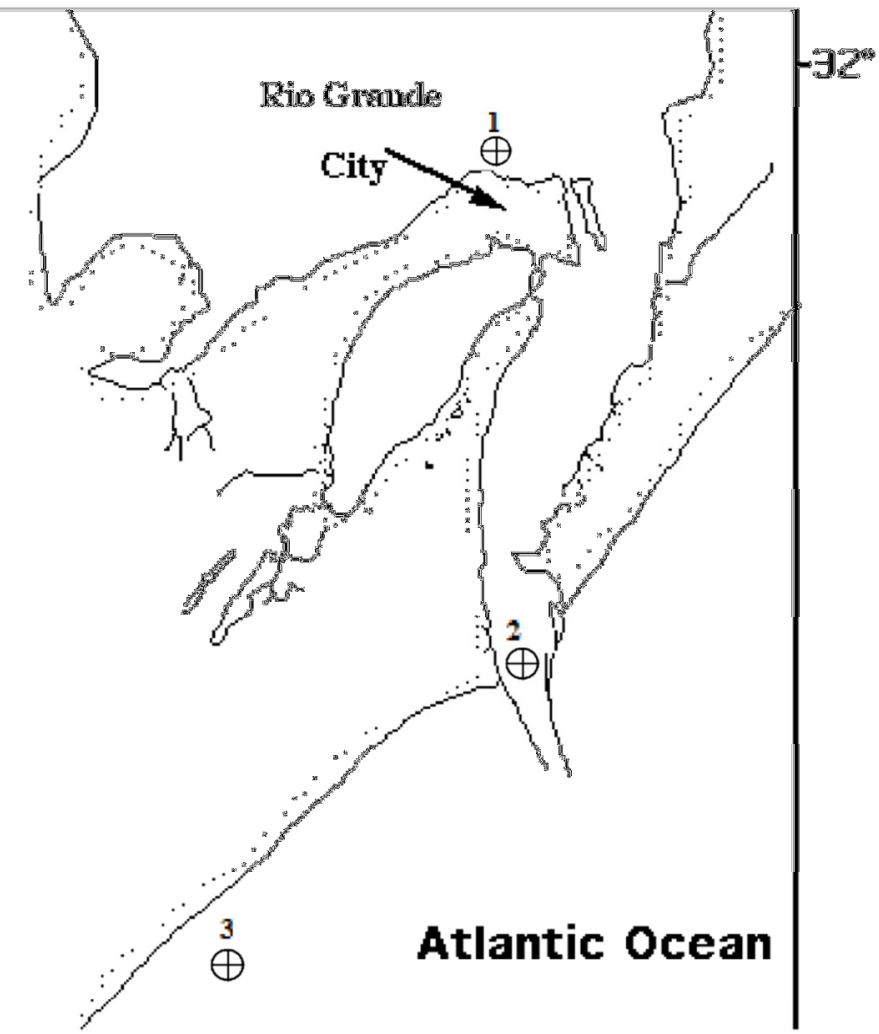

$52^{\circ} w$

FIGURE 1 - Localization of sampling sites: 1 - Museum 2 - Channel 3. Beach 


\section{Isolation and identification of fungi and yeasts}

Water samples were centrifuged at $4500 \mathrm{rpm}$ for 10 minutes to remove suspended material. Subsequently, the concentrated material was diluted in Phosphate Buffer Solution (PBS), $\mathrm{pH} 7.2$, at the ratios of 1:1,1:2, 1:3 and 1:4 (Busta et al. 1984). Fungi were diluted in PBS (Phosphate Buffer Solution), pH 7.2, with serial dilutions (decimal) up to 10-4. Aliquots of $10 \mu \mathrm{l}$ of each dilution were spread on the surface of plates containing Sabouraud agar with chloramphenicol 0,005\% (Acumedia Manufactures, Inc. Lansing, Michigan), and placed in a bacteriological incubator at $25^{\circ} \mathrm{C}$ (Busta et al. 1984). This operation was repeated in duplicate for each dilution. The cultures were observed daily for up to 07 (seven) days.

The identification at the genera level was based on the macro and micro morphology of the filamentous fungi, Apart from these characteristics, the growth velocity (time from sowing to initial view of the colony), mycelium surface appearance and pigmentation of the front and back of cultures were also observed (Alexoupoulos et al. 1996, Barnet \& Hunter 1998, Putzke \& Putzke 2002). The micro-morphological characteristics were verified using the slide culture technique (Ridell 1950). Yeasts were not identified.

\section{Statistical analysis}

The averages of biotic and abiotic variables between these two periods (April, May and June, 2007 and April, May and June, 2008) were compared by $t$ test. In order to test the association between the number of genera and isolates per genus and abiotic variables, a Stepwise multiple regression model was applied. Assumptions of the model were verified (Zar 1996, Hammer et al. 2001).

\section{RESULTS}

Water temperature was similar in the three stations and showed a clear seasonal pattern with the lowest value $\left(5^{\circ} \mathrm{C}\right)$ in July 2007 and the highest $\left(25^{\circ} \mathrm{C}\right)$ in January 2008 (Figure 2A).

Salinity varied according to the geographic location of each sampling site. At the Beach sampling site, salinity ranged from 20 to 33 , showing lower monthly variations compared to the Channel and Museum sites, where salinity ranged from 0 to 33 . Highest values were measured in autumn 2007 and summer 2008. (Figure 2B). The $\mathrm{pH}$ level remained stable throughout the study, with a slight variation at each sampling site $(7.0-8.2)$. 
A
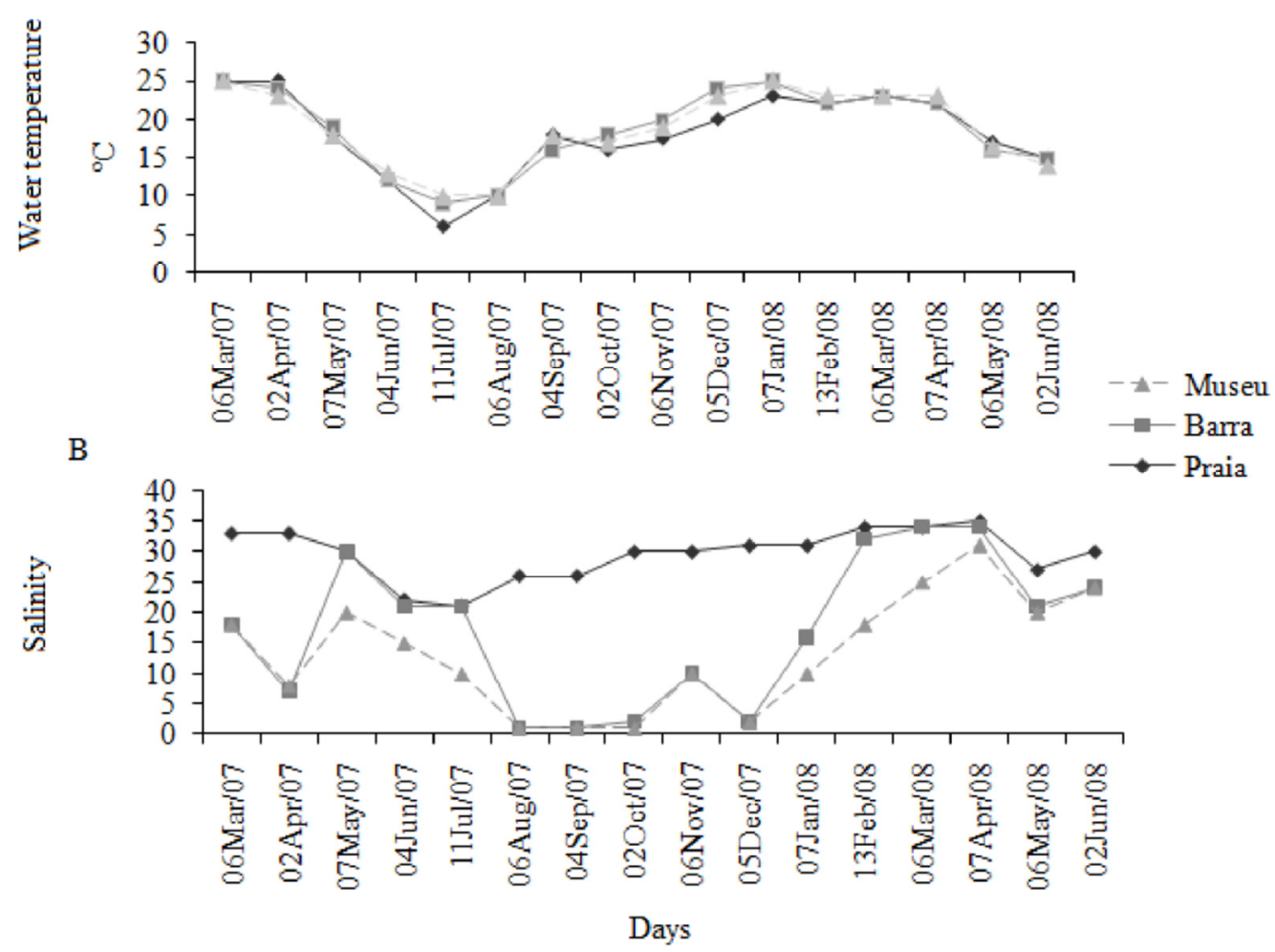

Figure 2. Water temperature (A) and salinitv (B) during experimental period.

FIGURE 2 - Water temperature (A) and salinity (B) during experimental period. 
Ammonium values were similar at the three sampling sites, with the highest value $(65 \mu \mathrm{M})$ measured in October 2007 at the Channel (Figure 3A). The concentrations of nitrite+nitrate were low at Beach except for September $2007(15 \mu \mathrm{M})$ while the Channel sampling site presented high concentrations between August $(15 \mu \mathrm{M})$ and December 2007(40 $\mu \mathrm{M})$. In the Museum the highest concentrations of these nutrients
$(40 \mu \mathrm{M})$ was measured in December 2007 (Figure $3 \mathrm{~B}$ ).

Phosphate values in samples showed different patterns for each site. At the Beach, phosphate varied between 0.75 and $2.0 \mu \mathrm{M}$ with maximum in October 2007. The site Channel was also highly variations, with variable between 0.75 and $3.5 \mu \mathrm{M}$ but the greatest values and variation was verified at the Museum sampling site $(3.3 \mu \mathrm{M})$ (Figure $3 \mathrm{C}$ ).

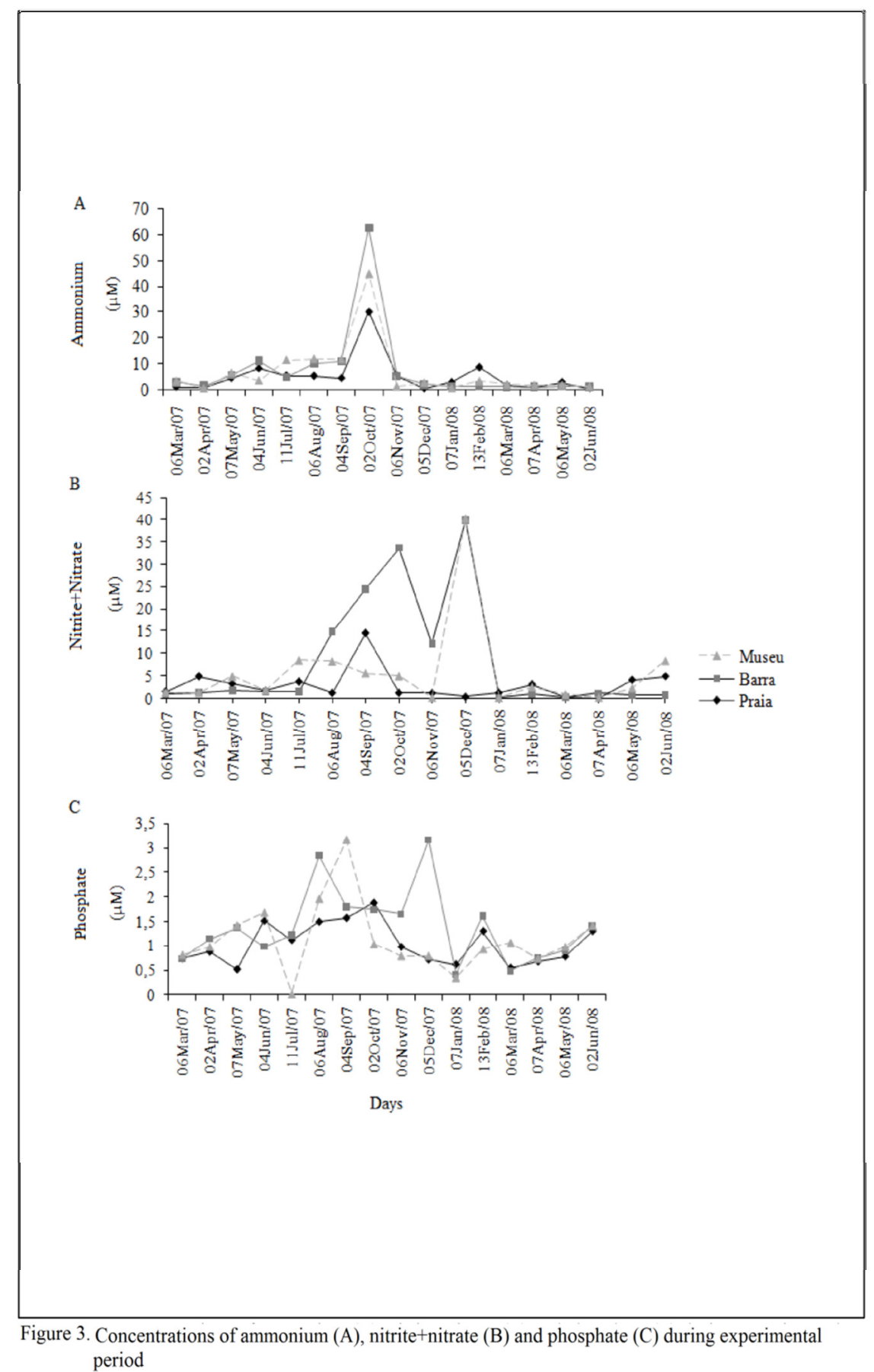

FIGURE 3 - Concentrations of ammonium (A), nitrite+nitrate (B) and phosphate (C) during experimental period. 
The following genera of filamentous fungi isolates were found: Alternaria, Aspergillus, Aureobasidium, Bispora, Botryoderma, Botryotrichum, Cladosporium, Chrysosporum, Helminthosporium, Monosporium, Papilospora, Penicillium, Trichoderma, Trichophyton, Actinomycetes and non-sporulated fungi. The most frequent fungal genera were Aspergillus. and Penicillium.

The highest number of isolates was found at Museum (85 isolates) (Figure 4A). The sites of Channel and Beach presented similar amounts of isolates, 35 and 39 respectively (Figure 4B and 4C).

Some fungi were characteristic of a single sampling site. For instance, the isolates of Botryotrichum, Cladosporium, Papulospora and Crysosporium were only found at the Beach sampling station. The Museum was the only station where Trichoderma, Helminthosporium, Trichophyton and Botryoderma were isolated; while Mucor was only isolated at the sampling station Channel the higher number of isolates Aspergillus at Museum was in May 2007, though this organism was isolated from this station during almost all the study period. Yeasts were found in 08 samples at this site and had the highest occurrence in samples fromApril, May and June 2007. Nonsporulated fungi were found in 07 samples with uniform values. Penicillium was found in 04 samples, the highest number of isolates in April 2007 (Figure 4A).

Among the isolated fungal groups, yeasts were found in 07 of the 11 samples from the site Channel and the highest occurrence occurred in and May 2007 samples, though this distribution was fairly uniform throughout the experimental period (Figure 4B).

Groups of non-sporulated fungi were found in 07 samples, showing elevated number of isolates in May, October and December 2007 and June 2008. Aspergillus was found in 04 samples, being most prevalent in March 2007(Figure 4B).

The yeasts are among the major isolated fungal groups at the Beach sampling site. They were found in 06 of 09 samples, with the greatest number of isolates in June 2007. Non-sporulated fungi were found in the samples from May to November, showing the highest number of isolates in September 2007. The genus Aspergillus was found distributed in 03 samples, showing the highest number of isolates in October 2007 (Figure 4C). 


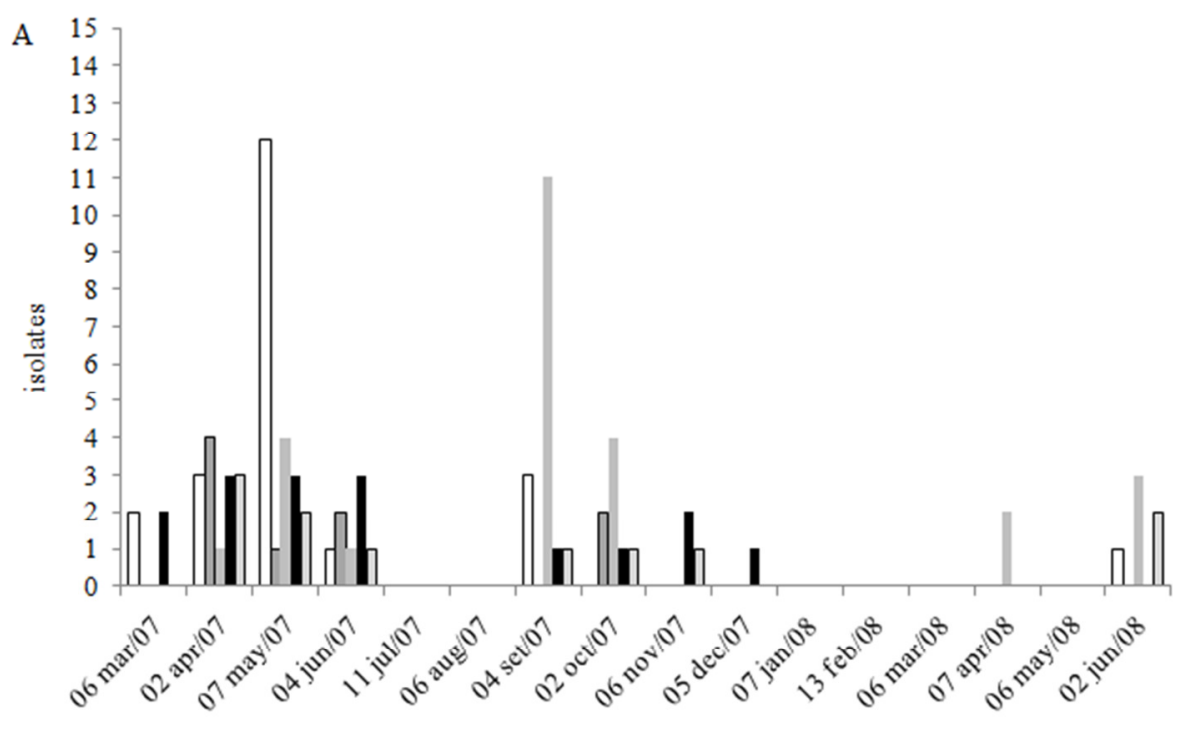

B
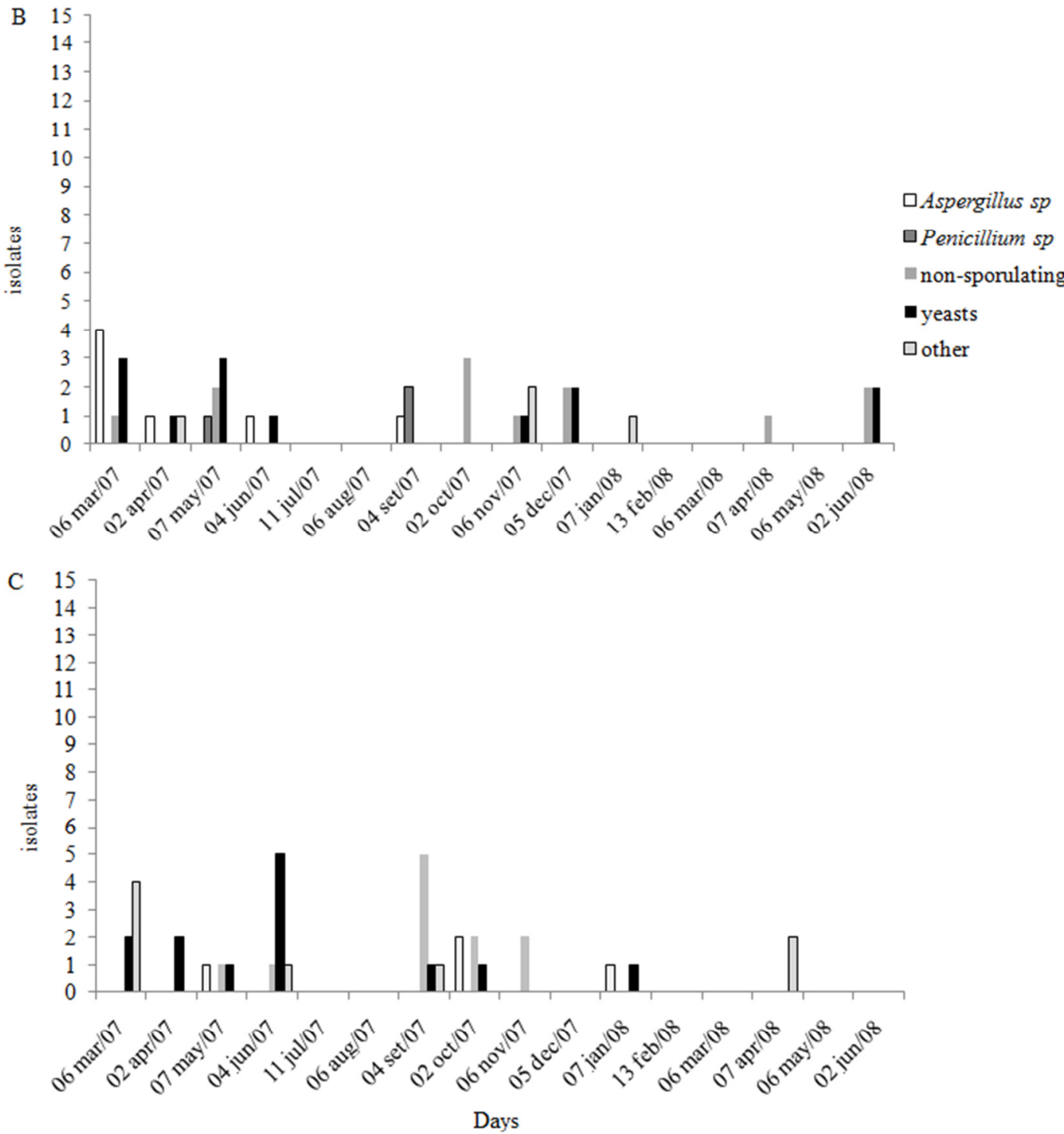

Figure 4. Isolates of different fungal genera at the Museu (A), Barra (B) and Praia (C) during the experimental period.

FIGURE 4 - Isolates of different genera of the Museum (A), Channel (B) and Beach (C). 
The statistical analysis showed significant correlation positive between the number of yeast isolates and salinity $(p=0.0145)$ and $\mathrm{pH}(\mathrm{p}=$ 0.040199). Moreover, significant correlations positive were found between the number of fungi genera and phosphate $(p=0.00477)$, nitrate $(p=0.022182)$ and $\mathrm{pH}(\mathrm{p}=0.024534)$.

\section{DISCUSSION}

The aquatic of fungi community is mainly composed of zoosporic fungi, aquatic hyphomycetes (mainly in submerged substrates), some representatives of basidiomycetes (usually phases of sexual reproduction), ascomycetes (including phases of sexual reproduction) and varying amounts fungi and yeasts of terrestrial origins (Sparrow 1968, Dick 1970). The most commonly found taxonomic groups in submerged substrates are the ascomycetes, basidiomycetes, chytridiomycetes and uniflagellate zoosporic fungi (Shearer et al. 2007). Besides, in polluted waters, the incidence of terrestrial origin fungi and yeasts is quite high (Schoenlein-Crusius et al. 2004).

In this study we have found 13 genera, being Aspergillus and Penicillium the most frequent. These genera were also dominant in the study of fungal diversity conducted by Gomes et al. (2008) in the Casa Caiada Beach, Northeastern, Brazil and were related to waters with high salinity and alkaline $\mathrm{pH}$. Contaminated sediments in the Santos Bay estuarine region in Southeastern Brazil presented Penicillium simplicissimum, Aspergillus terreus, Trichoderma and other filamentous fungi (Silva et al. 2003).

The highest number of fungal isolates in this study were registered between April and June 2007, and considerably smaller values were observed in the same period of 2008. The analysis of the abiotic factors of the two periods shows, that the salinity and $\mathrm{pH}$ values were higher in 2008, whereas concentrations of ammonia (Figure 4) were higher in 2007.

Salinity is a limiting growth factor of fungi (Mueller \& Bills 2004), especially for those from freshwater environments. Thus, it is likely that the lowest number of isolates obtained in 2008 is related to higher salinity in the estuary and coastal regions. Another fact that corroborates the effect of salinity in this study was the spatial gradient observed in isolates number between the stations Museum in the innermost site, and the beach.

As for the $\mathrm{pH}$, the optimum value for the growth of different types of fungi can vary greatly, but overall, most of them seem to grow best at $\mathrm{pH}$ levels between 4 and 7 (Alexoupoulos et al. 1996). The greatest number of fungi isolated from the sampling stations occurred in water samples with $\mathrm{pH}$ values between from 7 and 7.5. The greater number of isolated fungal genera related to higher levels of ammonia in April, May and June 2007, is probably related to the fact that besides carbon fungi require nitrogen for their growth. For obtaining nitrogen, fungi use organic or inorganic sources. The main organic sources are proteins, peptides and amino acids. Many fungi, however, obtain nitrogen from inorganic sources such as nitrates and ammonium salts (Cadick et al. 1994, Marzluf 1997).

It is noteworthy the fact that in this study the different sampling sites presented characteristic genera. The sampling station Beach was the only site where Botryotrichum, Cladosporium Papulospora and Crysosporium were found. The Museum was the only site where Trichoderma, Helminthosporium, Trichophyton and Botryoderma were observed, while Mucor was only found at the Channel. These located occurrences might be explained by the influence of factors such as salinity, temperature, substrates availability and diversity and nutrients in the water, as observed elsewhere (Jones \& Alias 1997).

For example, Trichoderma was found in Museum only when salinity was lower than at the other stations. Regragui \& Lahlou (2005) observed that soil salinity affects the reproductive capacity of Trichoderma harzianum with decrease in sporulation. Papulospora, which occurred only at the Beach, is mainly associated with decomposing plants. This species was also registered in a survey for identification of marine fungi in Thailand (Gareth et al. 2006).

When we tested the association between the number of genera and abiotic factors at the three sampling sites, a positive relationship was found with phosphate concentration. Several studies have shown that an increased concentration of nutrients in the water leads to a rise in fungal diversity (Sreedevi \& Rosamma 2008, Gullis \& Suberkropp 2003a, Gullis \& Suberkropp 2003b, Gullis \& Suberkropp 2004, Pascoal \& Cassio 2004). Increasing phosphate 
concentration was related with an enhanced activity of decomposing substrates by some authors (Sridhar \& Bärlocher 2000, Gullis \& Suberkropp 2003a). On the other hand, Rosemond et al. (2002) found no effect of phosphate on the decomposition of leaf in water by fungi. Moreover, Fernandes et al. (2009), studied the impact of multiple stressors on freshwater fungi and found that greater exposure to phosphate led to changes in fungal community structure related to its diversity and species abundance.

The highest amount of yeasts isolates was found at the Beach sampling site. Furthermore, this study revealed a positive association of these organisms with salinity; and a negative association with $\mathrm{pH}$. Yeasts are known to be a normal usual component of the oceanic biota (Kriss et al. 1967, Fell 1967). The occurrence of yeasts in coastal marine waters is well established (Meyers \& Ahearn 1974, Kohlmeyer \& Kohlmeyer 1979), and results from its role in the decomposition of organic substrates, nutrient recycling and biodegradation of hydrocarbons (Meyers \& Ahearn 1974, Lachance et al.1976). Species frequently collected from sea water were obtained from much polluted areas (Fell \& Van Uden 1963) and yeasts generally decrease with the increasing distance from the coast. Areas of open and deep ocean usually contain from 10 to 100 yeast cells $L^{-1}$ while coastal areas support populations of up to 1.000 yeast cells $L^{-1}$ (Fell 1976). The ability of yeasts to utilize various carbohydrates present in marine vegetation can be highly valuable for its survival in marine environments (Roth et al. 1964).

In Brazil, the presence of yeasts in seawater has been reported in quantitative and qualitative analysis (Florianópolis, SC, Faraco \& Faraco 1960; Recife, PE, Queiroz 1972) in quantitative and qualitative analysis. On the beaches of Olinda, PE, yeasts isolated from the sand and seawater. These authors determined parameters of rainfall, $\mathrm{pH}$, temperature and salinity of water and sand, having found the highest frequencies of yeasts in periods of high rainfall (Loureiro et al. 2005).

It is likely that the yeasts isolated in the present study are halophilic or halotolerant of terrestrial origin. Sreevedi \& Rosamma (2008) argues that the salinity tolerance does not distinguish marine yeast species from terrestrial ones, because almost all yeasts grow at sodium chloride concentrations higher than those found in seawater. It seems that in the yeast biology enables, the colonization of diverse substrates and the survival under wide range of salinity and osmotic pressure, which have made the yeasts one of the most successful organisms in the marine environment, even at great depths (Bass et al. 2007).

In summary, this study demonstrated the presence of several fungi and yeasts in the waters of the Patos Lagoon estuary and adjacent coastal area, with the highest number of fungal isolates in this study were registered between April and June 2007. However, we emphasize the necessity of further studies on the biology and ecology of these organisms.

\section{ACKNOWLEDGEMENT}

This work was supported by financial resources from Brazilian National Council for Scientific and Technological Development (CNPq). We thank to the reviewers and the program postgraduate from Biological Oceanography, Federal University of Rio Grande (FURG), RS, Brazil.

\section{REFERENCES}

ABREU, PC, BB BIDANDA \& C ODEBRECHT. 1992. Bacterial dynamics of the Patos Lagoon estuary, Southern Brazil $\left(32^{\circ} \mathrm{S}\right.$, $52^{\circ} \mathrm{W}$ ): Relationship with phytoplankton and suspend material. Estuar. Coast. Shelf Sci., 35, (6), 621-635.

ALEXOUPOULOS, CJ, CW MIMS \& M, BLACKWELL. 1996. Introductory Micology. $4^{\text {th }}$. ed. New York, Jonh Wiley \& Sons. 869p.

BARNET, HL, BB HUNTER. 1998. llustrated genera of imperfect fungi. FourthEdition. Minnesota, APS Press. St. Paul. 218p.

BASS, D, A HOWE, N BROWN, H BARTON, M DEMIDOVA, H MICHELLE, LH LI, SC SANDERS, S WATKINSON, S WILLCOCK \& TA RICHARDS. 2007. Yeast forms dominate fungal diversity in the deep oceans. Proc. Biol. Sci., 274: 3069-3077.

BREPOHL, DC, PC ABREU, AMB ANÉSIO, CSB COSTA. 1996. Variação da biomassa microbiana durante a degradação da macrófita Scirpus maritimus var. macrostachyus (Lam) Michx. Rio Grande, Revista Atlântica., 18: 13-26.

BUSTA, FF, EH PETERSON, DM ADAMS, MG JOHNSON. 1984.Clony count method. In: Speck, ML., (ed.). Compendium of methods for the microbiological examination of foods. American Public Health Association, Washington D.C. Washington D.C, American Public Health Association., 62-77.

CADDICK, MX, D PETERS, A PLATT. 1994. Nitrogen regulation in fungi. Antonie van Leeuwenhoek., 64: 169-177.

DICK, MW. 1970. Saprolegniaceae on insect exuviae. Trans. Br. Mycol. Soc., 55 (3): 449-458.

FARACO, BFC, BA FARACO. 1960. Poluição hídrica micológica. Rev. Bras. Med., 33: 210-220.

FELL, JW. 1967. Distribution of yeasts in the Indian Ocean. Bull. Mar. Sci., 17: 454-470.

FELL, JW, N VAN UDEN. 1963. Yeasts in marine environments. In: 
Oppenheimer, C. H. (ed.). Symposium on Marine Microbiology. Charles C. Thomas, Springfield, 329-340.

FELL, J. W. (1976). Yeasts in oceanic regions. In: Jones, E. B. G. (ed). Recent Advancesin Aquatic Mycology. New York. Wiley. p. 93-124.

FERNANDES, I, S DUARTE, F CASSIO , C PASCOAL. 2009. Mixtures of zinc and phosphate affect leaf litter decomposition by aquatic fungi in streams. Sci. Total Environment., 407: 4283-4288.

GARETH, JEB, A PILANTANAPK, I CHATMALAI, JJ SAKAYARO, S PHONGPAICHIT, R CHOEYKLIN. 2006. Thai marine fungal diversity. Songklanakarin J. Sci. Technol., 28 (4): 687-708.

GOMES, DNF, MAQ CAVALCANTI, MJS FERNANDES, DMM LIMA, JZO PASSAVANTE. 2008. Filamentous fungi isolated from sand and water of "Bairro Novo" and "Casa Caiada" beaches, Olinda, Pernambuco. Brazil. Braz. J. Biol., 68 (3): 577-582.

GULLIS, V, K SUBERKROPP. 2004. Effects of whole-stream nutrient enrichment on the concentration and abundance of aquatic hyphomycete conidia in transport. Mycologia., 49: 1437-47.

GULLIS, V, K SUBERKROPP. 2003a. Effect inorganic nutrients on relative contribuitions of fungi and bacteria to carbon flow from submerged decomposing leaf litter. Microb. Ecol., 45,11-9.

GULLIS, V, K SUBERKROPP. 2003b. Leaf litter decomposition and microbial activity in nutrient-enriched and unaltered reaches of headwater stream. Freshw. Biol., 48: 123-34.

HAMMER, O, DAT HARPER, PD RYAN. 2001. Palaentological statistics

software for education and data analysis. Palaentologia Electronica; Valencia.

HICKENBICK, GR, AL FERRO, PC ABREU. 2004. Produção de detritos de macrófitas emergentes em uma marisma do estuário da lagoa dos Patos: taxas de decomposição e dinâmica microbiana. Atlântica., Rio Grande; 26: 61-75.

JONES, EBG, A ALIAS. 1997. Biodiversity of mangrove fungi. In: Hyde, K. D. (ed). Biodiversity of tropical microfungi. Hong Kong University Press, Hong Kong, p. 71-92.

KOHLMEYER, J, E KOHLMEYER. 1979. Marine mycology: the higher fungi. Academic Press, New York.

KRISS, AE, E MISHUSTINAI, N MITSKEVICH, EV ZEMTSOVA. 1967. Microbial Population of Ocean and Seas. London. Arnold.

LACHANCE, M.A, M MIRANDA, MW MILLAR, HJ PHAFF. 1976. Dehiscence and active spore release in pathogenic strains of the yeast Metschnikowia bicuspidate var. australis: possible predatory implication. Can. J. Microbiol., 22: 1756-1761.

LOUREIRO, STA, MAQ CAVALCANTI, RP NEVES, JZO PASSAVANTE. 2005. Yeasts isolated from sand and sea water in beaches of Olinda, Pernambuco state, Brazil. Braz. J. Microbiol. 36: 333-337.

MARZLUF, GA. 1997. Genetic regulation of nitrogen metabolism in the fungi. Microbiol. Mol. Bio., 61:17-32.

MEYERS, SP, DG AHEARN. 1974. Implication of Yeasts and Yeastlike Fungi in Marine Process. Veroff. Inst. Meeresforsch. Bremen., Suppl. 5: 321-338.

MUELLER, GM, GF BILLS. 2004. Introduction. In: Mueller, GM, Bills, GF, Foster, MS. (eds). Biodiversity of fungi: inventory and monitoring methods. Elsevier Academic Press, San Diego, p. 1-4.

PASCOAL, C, F CASSIO. 2004. Contribuition of fungi and bacteria to leaf litter decomposition in a polluted river. Appl. Environ. Microbiol; 70: 5266-73.

PUTZKE, J, MTL PUTZKE. 2002. O reino dos fungos. Volume 2. Santa Cruz do Sul. Editora Edunisc.. 829p.

QUEIROZ, LE. 1972. Análise Quanti - Qualitativa de leveduras isoladas de algasmarinhas. I - Recife, Instituto de Micologia da Universidade Federal de Pernambuco, publ. 677.

REGRAGUI, A, H LAHLOU. 2005. Effect of Salinity on in vitro Trichoderma harzianum Antagonism Against Verticillium dahlia. Pak. J. Biol. Sci., 8 (6): 872-876.

RIDELL, RW. 1950. Permanent stained mycological preparations obtained by slide culture. Mycologya., 42: 265-70.

ROSEMOND, AD, CM PRINGLE, A RAMIREZ, MJ PAUL, JL MEYER. 2002. Landscape variation in phosphorus concentration and effects on detritus-based tropical streams. Limnol. Oceanogr., 47: 278-89.

ROTH, FJ, PA ORPURT, DG AHEARN. 1964. Occurrence and distribuition of fungi in a subtropical marine environment. Can. J. Bot., 42: 375-383. SCHOENLEIN-CRUSIUS, IH, CLA PIRESZOTARELLI, AI MILANEZ. 2004. Amostragem em Limnologia: Os fungos Aquáticos. In: Bicudo, C. E. M,; Bicudo, D. C. Amostragem em Limnologia. 2. São Carlos.Ed. Rima Editora. p. 179-191.

SEELIGER, U, C ODEBRECHT, JP CASTELO. 1997. Os Ecosssistemas Costeiros e Marinho do Extremos Sul Do Brasil. Rio Grande, RS. Ed. Ecoscientia. 341p.

SHEARER, CA, E DESCALS, B KOHLMEYER, J KOHLMEYER, L MAREVANOVÁ, D PADGET, D PORTER, HÁ RAJÁ, JP SCHIMIT, HÁ THORTON, H VOGLYMAYR. 2007. Fungal biodiversity in aquatic habitats. Biodivers. Conserv., 16: 49-67.

SILVA, M, CE CERNIGLIA, JV POTHULURI, VP CANHOS, E ESPOSITO. 2003. Screening filamentous fungi isolated from estuarine sediments for the abilityto oxidize polycyclic aromatic hydrocarbons. World JMicrobiol. Biotechnol., 19: 399-405.

SPARROW, FK. 1968. Ecology of freshwater fungi. In: Gainswoth, GC, Sussman, AS. (eds). The fungi. New York. Academ. Press. p. 41-91.

SREEDEVI, NK, P ROSAMMA. 2008. Marine yeasts - a review. Yeast., 25: 465-483.

SRIDHAR, KR, F BÄRLOCHER. (2000). Initial colonization, nutrient supply, and fungal activity on leaves decaying in streams. Appl. Environ. Microbiol., 66: 1114-9.

STRICKLAND, JDH, TR PARSON. 1972. A practical handbook of seawater analysis. Fisheries Research Board of Canada, Ottawa. 310p.

VASCONCELOS, WE, MS RIOS, AH SOUSA, EV MEDEIROS, MCG SILVA, PB MARACAJÁ. 2003. Caracterização química e enzimática de Cunninghamella isoladas de manguezal. Revista de Biologia e Ciências da Terra., 3: 2.

UNESCO. 1983. Chemical methods for use in marine environmental monitoring. Intergovernmental Oceanographic Comission. Manual and Guides 12, Paris.

ZAR, JH. 1996. Biostatistical analysis. New Jersey .Prentice Hall. 